\title{
Dynamic capabilities, expert and entrepreneurial learning
}

\author{
C.J. Lecler* and J. Kinghorn \\ Gordon Institute of Business Science, University of Pretoria, PO Box 787602, Sandton, 2146, Johannesburg, South Africa. \\ carynlecler@telkomsa.net
}

\begin{abstract}
This article focuses on how managers sense and seize opportunities for learning and developing dynamic capabilities in organisations. An approach of building process theory from cases traces learning events in the technological innovation approaches of three securities custodians facing an increasingly dynamic market. The article extends and elaborates the dynamic capability learning framework (Lecler, 2013) which proposes that managers recognise learning opportunities through two types of learning, expert and entrepreneurial, with variants for technological and organisational problem solving. The concept of entrepreneurial learning is further elaborated to help explain differences in the learning patterns found. Distinctive characteristics of the two types of learning are proposed pertaining to opportunity recognition and realisation, and the problem solving strategy. The framework helps to analyse data in terms of four learning patterns: expert honing and aligning, and entrepreneurial shaping and configuring. Further, entrepreneurial learning is suggested to facilitate dynamic capability development in a highly dynamic environment.
\end{abstract}

*To whom all correspondence should be addressed.

\section{Introduction}

Following Teece (2009: 200) dynamic capabilities are best understood as "the capacity to sense and seize opportunities, and then transform and reconfigure as competitive forces dictate" (own italics). As higher order capabilities, dynamic capabilities govern the rate of change of ordinary capabilities (Collis, 1994; Winter, 2003), those which enable a firm to make a living.

Seen from this perspective, there is a close link between dynamic capabilities and organisational learning. Organisational learning occurs when learning is embedded into the active life of the organisation (Crossan, Lane, \& White, 1999). It can be defined as a change in the organisation's behaviour that occurs as a function of experience (Argote, 2011).

Organisational learning is a multilevel process transcending individual, group, and organisational levels (Crossan et al., 1999). Even so, it is individuals who acquire knowledge. Learning occurs through them (Argote, 2011) because only they have the cognitive capability to understand cause-effect relationships and link stimuli with response information (Walsh \& Ungson, 1991).

This, of course, places managers in a pivotal position. Although all organisational participants are engaged in some form of learning, organisational continuity and innovative capacity depend on the role that managers play in the learning process. If dynamic capabilities themselves involve sensing and seizing opportunities, their development is likely to involve sensing and seizing of learning opportunities; and then the question is: how do managers sense and seize learning opportunities?
This article explores how managers come to sense and seize learning opportunities. It draws on some of the findings of a broader study on how dynamic capabilities develop through learning (Lecler, 2013) and extends the analysis. More broadly, it aims to extend existing theory on managerial cognition.

The theoretical approach highlights research relating to the role of managerial cognition in the development of dynamic capabilities. It identifies multiple perspectives on dynamic capability learning and suggests that an improved understanding of opportunity recognition in these perspectives is required. It also highlights recent work on managerial cognition in strategy and organisational learning research as well as in entrepreneurship research. The theme of multiple views on learning and opportunity recognition is extended, suggesting that a better understanding of these views is required.

Two research strategies are employed in the empirical approach. First, building theory from cases (Eisenhardt, 1989a; Eisenhardt \& Graebner, 2007) examines technological innovation in three securities custodians operating in an evolving market, which became highly dynamic. The fast paced financial markets industry provides a case setting where dynamic capabilities are likely to be developed. Second, an analysis of process data aims to find similar learning patterns across the custodians and to develop process theory. In particular, a focus on strategy process in dynamic capabilities research may facilitate answering 'how' questions in more fine-grained detail (Helfat, Finkelstein, Mitchell, Peteraf, Singh, Teece, \& Winter, 2007: Chapter 3).

The research strategies are combined in a novel analytical approach. Building theory from cases is more a positivist 
approach (Eisenhardt \& Graebner, 2007) and the approach taken to analysing process data is more an interpretivist approach. A positivist approach aims to find general patterns that are consistent across multiple settings, while an interpretivist approach aims to understand the meaning of general concepts in their specific operation and show how a general pattern looks in practice (Lin, 1998). The analysis aims to find learning patterns based on causal relationships and go further to interpret their meaning by identifying underlying causal mechanisms or pattern characteristics. Combining both approaches creates more clarity about mechanism and relationship and helps to correct for biases (Lin, 1998).

The findings show that managers recognise learning opportunities through two learning patterns, expert and entrepreneurial, with variants of these patterns for both technological and organisational problem solving. Based on the dynamic capability learning framework (Lecler, 2013), a more detailed and extended characterisation of the two types of learning relating to opportunity recognition is developed to explain the findings. The concept of entrepreneurial learning is further elaborated. In addition, the implications of entrepreneurial learning are highlighted, with respect to the overall aim of gaining a better understanding of dynamic capability development.

\section{Managerial cognition}

Managerial cognition refers to managerial beliefs and mental models that provide a basis for decision making (Adner \& Helfat, 2003). An alternative term is dominant logic, which refers to a conceptualisation of the business shared among the dominant group of managers and expressed in learnt problem solving behaviour (Prahalad \& Bettis, 1986). Distinct from individual cognition (Cohen \& Bacdayan, 1994; Weick \& Roberts, 1993), managerial cognition represents a form of organisational learning. Literature on managerial cognition in dynamic capability development, organisational renewal, and entrepreneurship is briefly discussed.

\section{Dynamic capability development}

Part of the strategy domain, dynamic capabilities research aims to understand how an organisation can achieve and sustain a competitive advantage in the face of environmental change (Teece, Pisano \& Shuen, 1997). It offers three perspectives on their development, each emphasising different aspects of their nature. A better understanding of cognition in driving capability development is likely to benefit dynamic capabilities research (Gavetti, 2005).

In order to better understand how dynamic capabilities develop through learning, it is helpful to first elaborate on the nature of dynamic capabilities; itself debated (Di Stefano, Peteraf, \& Verona, 2010; Easterby-Smith, Lyles, \& Peteraf, 2009; Helfat \& Peteraf, 2009). Given a research consensus that organisational learning can manifest in cognitive or behavioural change (Argote 2011; Easterby-
Smith, Crossan, \& Nicolini, 2000), higher level learning involves more extensive cognitive development (Fiol \& Lyles, 1985) evident in capabilities. The cognitive element of dynamic capabilities is emphasised by referring to them as capacities to sense and seize opportunities and transform an organisation. The term 'capacity' indicates a minimal ability (Helfat \& Peteraf, 2009) suggesting that it embodies past learning and accumulated knowledge that can be brought to bear on a particular situation. In this sense, a dynamic capability is underpinned by processes and other resources (Teece, 2007) which can be used to achieve its objectives. The behavioural element of dynamic capabilities is emphasised by referring to them as higher order capabilities. Capabilities themselves comprise high level routines oriented towards specific objectives (Winter, 2003), where a routine is a repeatable, recognisable pattern of action involving multiple participants and interdependent actions (Feldman \& Pentland, 2003). Given that change can alternatively made by means of ad hoc problem solving, the development of higher order capabilities is only warranted in changing environments because investment is required to sustain the patterned activity (Winter, 2003).

First, an evolutionary perspective on dynamic capability learning is borne out of evolutionary economics (Nelson \& Winter, 1982) and concerns a firm's adaptive ability. It directs attention to routines and path dependence (Helfat \& Peteraf, 2009). It is based on the traditional evolutionary cycle of variation, selection, and retention with external selection due to environmental competition and internal selection of routines. In a dynamic environment, emphasis shifts from variation to selection due to an abundance of varied experiences (Eisenhardt \& Martin, 2000). Dynamic capability development involves learning how to learn and requires creating variation in learning and selecting appropriate ways to learn, where learning itself is a technology (Levitt \& March, 1988). Theoretical work argues that dynamic capabilities evolve through a knowledge evolution cycle where knowledge articulation and codification practices help to make knowledge explicit and facilitate the selection stage in the cycle; in particular, the creative processes, more than the outputs, may help the causal understanding of managers (Zollo \& Winter, 2002). Empirical work supports the argument in bank acquisition integration (Zollo \& Singh, 2004) and in alliance cooperation (Kale \& Singh, 2007). More recently, in a simulation study, Romme, Zollo, and Berends (2010) found that in a highly dynamic environment, knowledge articulation was useful but that knowledge codification had limited use, which they argue to be due to inertial effects. They also note that the question of how dynamic capabilities develop remains open to debate.

A second perspective on the evolution of dynamic capabilities contrasts the way they are developed through learning and hence, their nature, in moderately and highly dynamic markets. Eisenhardt and Martin (2000) argue that as environmental change becomes increasingly non-linear and less predictable, dynamic capabilities rely more on creating situation specific knowledge than on existing knowledge. Similarly, learning efforts guiding their 
evolution are argued to become less analytical and more experiential, informed by real time information on markets. Thus, they argue that dynamic capabilities both match and create market change. Further, they suggest that in highly dynamic markets, a path breaking logic of strategic opportunity, to create a series of temporary advantages, is required in addition to a path dependent logic of strategic leverage. Empirical findings on product development in fast moving, uncertain environments support the effectiveness of experiential learning strategies rather than a more planned approach (e.g. Eisenhardt, 1989b; Eisenhardt \& Tabrizi, 1995).

Third, a perspective on dynamic capabilities as 'evolution with design' extends the idea of both matching and creating market change. In this perspective, an organisation can adapt to, as well as shape market change through innovation (Teece, 2007). By implication, dynamic capability learning also involves 'evolution with design'. This perspective highlights the cognitive element of dynamic capabilities in the design role of managers. It is part of the dynamic capabilities framework (Teece, 2007; Teece et al., 1997) and suggests a broader role for managers, beyond selecting new routines in an evolutionary perspective, to also involve selecting and orchestrating assets prior to routinisation (Teece, 2009). The broader role may be related to the framework's concern with both technological and organisational assets. Teece (2009) notes that orchestrating assets involves assembling and combining intangible assets, such as knowledge assets, into "value yielding combinations'. In particular, he suggests that entrepreneurial management is important in selecting and assembling complementary assets, as well as in shaping learning processes. The dynamic capabilities framework includes both well-known theoretical views on entrepreneurship and puts forward a neo-Schumpeterian theory of the firm based on the nature of the innovation process. In the Kirznerian view on entrepreneurship (Kirzner, 1973 in Teece, 2007), entrepreneurs with differential access to existing information can recognise opportunities and then work to restore equilibria; whereas in the Schumpeterian view (Schumpeter, 1934 in Teece, 2007), entrepreneurs can disrupt equilibria by creating opportunities with new knowledge (Teece, 2007).

Empirical research supports the design role of managers in developing capabilities. For example, Adner and Helfat (2003) found that managerial decisions on corporate downsizing affected profitability over time in airline firms facing regulatory changes; Kaplan (2008) found that changes in managerial attention affected investment patterns in communication technology in firms facing a fibre-optic revolution; and O'Reilly, Harreld and Tushman (2009) found that explicit design of new business commercialisation enabled an information technology firm to pursue both emerging and mature market strategies at the same time.

In summary, research on dynamic capability and capability learning highlights the role of managerial agency. In an evolutionary perspective, it suggests that the explicit learning of managers may help the selection of new learning routines. Further, in highly dynamic environments, more experiential learning strategies may create path breaking change. In particular, the design role of managers may shape learning processes and reconfigure learning assets. The research suggests that a better understanding of opportunity recognition as it relates to selecting routines and shaping learning processes is required.

\section{Organisational renewal}

Strategy and organisational learning research highlights the nature of managerial learning in highly dynamic environments and of managerial cognition developed as result. Theoretical work points to more active learning strategies, due to new problems and a perceived need to develop new opportunities, which can involve an enacting mode or a discovery mode of interpretation, depending on the extent to which managers believe the environment is analysable (Daft \& Weick, 1984). It suggests limits to an adaptive process, in terms of recognising path breaking opportunities, especially under conditions of causal complexity and uncertainty. For example, Denrell, Fang and Winter's, (2003) refer to a strategic opportunity as existing wherever prices do not reflect the value of a resource's best use, implying that the discovery process is likely to be serendipitous; an unintended consequence of activities with a different purpose. They suggest that the development of a strategic path breaking opportunity is unlikely to follow a similar adaptive process, but could be part of a successful search, based on evidence in the literature that these opportunities tend to be context dependent.

Empirical work suggests that changes in managerial cognition are linked to strategic action. For example, in the strategic renewal of a railroad company Barr, Stimpert and Huff (1992) found that a shift in strategic thinking was directly linked to strategic actions and intentions. Renewal is suggested to involve noticing environmental changes and being able to link them to strategy and to modify the relationship over time. More recent research involving simulation under complex environmental conditions, suggests that analogical reasoning can be an effective strategy in a dynamic environment, but relies on prior experience. Analogical reasoning enables the transfer of experience from one setting to another and is suggested to be useful when a manager's prior experience allows a rich appreciation of a strategic problem (Gavetti, Levinthal \& Rivkin, 2005). Cognitive representations of managers were found to guide and constrain local incremental search (Gavetti \& Levinthal, 2000) and analogical reasoning was found to lead to the greatest long run advantage over local incremental search processes (Gavetti et al., 2005). Commenting on the latter, Farjoun (2008) argues that analogical reasoning approaches based on more abstract analogies can generate unique and novel solutions to partially construct the environment.

Research relating to the development of managerial cognition in changing environments suggests that managers 
form common types of beliefs and simple theories. Prolonged use of adaptive sensemaking practices leads to the development of common cognitive frameworks across firms, where process is emphasised over content because content oriented beliefs can become rapidly outdated (Bogner \& Barr, 2000). Empirical work provides support for the argument. As firms gained process experience in entering new markets, Bingham and Eisenhardt (2011) found that managers learnt portfolios of heuristics, or simple rules, to effectively capture opportunities. Common types of heuristics were found across firms, such as selection and procedural, and the heuristics became more sophisticated and abstract as experience was gained. They suggest that heuristics may be a rational strategy in unpredictable environments.

In summary, strategy and organisational learning research in dynamic environments suggests that both adaptive and enacting learning strategies can lead to the recognition of opportunities. In particular, work on analogical reasoning approaches extends the idea of both matching and creating market change. The research also suggests that common types of beliefs and simple theories are formed by managers to guide problem solving.

\section{Entrepreneurship}

Finally, research on entrepreneurship addresses opportunity recognition more directly. Entrepreneurship has traditionally been seen as relating to a type of person. More recently, Shane and Venkataraman (2000) argue that entrepreneurship is a process. They describe the Kirznerian view as a way in which temporal and spatial inefficiencies is an economy are discovered and reduced (Kirzner, 1997 in Shane \& Venkataraman, 2000) and the Schumpeterian view as product and process innovation where the generative source of the change process is entrepreneurially-driven (Schumpeter, 1934 in Shane \& Venkataraman, 2000).

Little advance has been made on the entrepreneurial process in organisations (Shane, 2012). A notable exception is Dutta and Crossan's (2005) argument that the two views on the nature of entrepreneurial opportunities can be reconciled by seeing the phenomenon as a learning process. They relate expert intuition and entrepreneurial intuition in Crossan et al.'s (1999) multilevel organisational learning framework to the two views. In the framework, entrepreneurial intuition is future possibility oriented and expert intuition is suggested to be past pattern oriented. More specifically, expert intuition is related to the Kirznerian view and the discovery of opportunities; and entrepreneurial intuition is related to the Schumpeterian view and the enactment of opportunities. Further, they suggest that the subjective nature of the Kirznerian view may also involve opportunity enactment due to an interpretation of the context, and in this sense, it is argued to also relate to entrepreneurial intuition.

The research provides further insight into opportunity discovery and enactment processes. Opportunity discovery is likely to be based on prior knowledge required to recognise it and the development of cognitive schema required to evaluate it (Shane \& Venkataraman, 2000). Empirical work shows that entrepreneurs discover opportunities based on prior related knowledge; for example, to exploit a technology invention (Shane, 2000) and to exploit business opportunities (Baron \& Ensley, 2006). Discovery of an opportunity involves recognising the value of new information based on knowledge already possessed rather than searching for required knowledge, consistent with the Kirznerian view on entrepreneurship (Shane, 2000). Experience may help to 'connect the dots' due to well-developed cognitive prototypes or templates of 'ideal' opportunities (Baron \& Ensley, 2006)

Opportunities made and enacted may involve a design process. Venkataraman, Sarasvathy, Dew and Forster, (2010) argue that opportunities are artefacts made through the interactions of stakeholders using materials and concepts found. Because of their contingent nature, artefacts are argued to embody a teleological process and are phenomena that can be designed. In a teleological process, an entity is assumed to be purposeful and adaptive and constructs an envisioned end state, takes action to reach it, and monitors the progress (Van de Ven \& Poole, 1995). The implication of designed artefacts is that the value of a particular resource becomes contingent on how it is used (Venkataraman et al., 2010). In one of the first empirical studies to focus on the cognitive processes involved in opportunity recognition, Gregoire, Barr and Shepherd (2010) found that entrepreneurs used their prior knowledge of markets to search for opportunities of new technologies. They found that opportunity recognition based on a search used cognitive processes of structural alignment that draw on prior knowledge. They contrast their results with the use of cognitive processes based on prototypes or templates of 'ideal' opportunities (Baron \& Ensley, 2006), suggesting that the latter refers more to the evaluation of opportunities.

In summary, entrepreneurship research suggests that opportunity discovery is an evaluative rather than a search process; in contrast, opportunity enactment is based on an intentional search. A common theme in the literature is that there are multiple views on opportunity recognition and a better understanding is required.

\section{Methods: Building process theory from cases}

The research design is a multiple case design with three organisations. A limited number of cases enables comparison and contrast to either produce similar results (literal replication) or produce contrary results for predictable reasons (theoretical replication) (Yin, 2003). A process approach is used to explain how a change occurs over time based on a sequence of events in the development of an organisation (Van de Ven, 2007; Van de Ven \& Poole, 2005). The case setting is the securities settlement industry, an essential complement to the securities trading industry in financial markets. Technological innovation involving various information systems development initiatives is the 
strategic process underlying dynamic capability development.

The organisations in the study were the securities custodian businesses of three banks; each custodian operating as a semi-independent unit in the market. Over the span of the study period of about 10 years, the market evolved from relatively stable to highly dynamic, making it a suitable setting to study dynamic capability learning. The custodians were selected as the three in the market most likely to develop them for two reasons: they held a significant and dominant market share and can be described as 'market players'; and they all became globally competitive, indicated by their market ratings in a global market survey. They could both adapt to and shape the custody market.
During that time, the custodians underwent a similar and interconnected journey because they all developed technological links to a platform organisation at an early stage, in the first and main one of two major market initiatives each involving a technological transition. Thus, comparative data could be collected from the organisations. A drawback of the particular setting was that it was a highly specialised industry. Prior related experience of the first author as well as multiple, comparative data sources helped ensure accurate data interpretation. For analysis purposes, the data was grouped into four stages or 'temporal brackets' (Langley, 1999) shown in Table 1, namely: market planning, main technological transition, market evolution, and current outlook.

Table 1: Case setting description

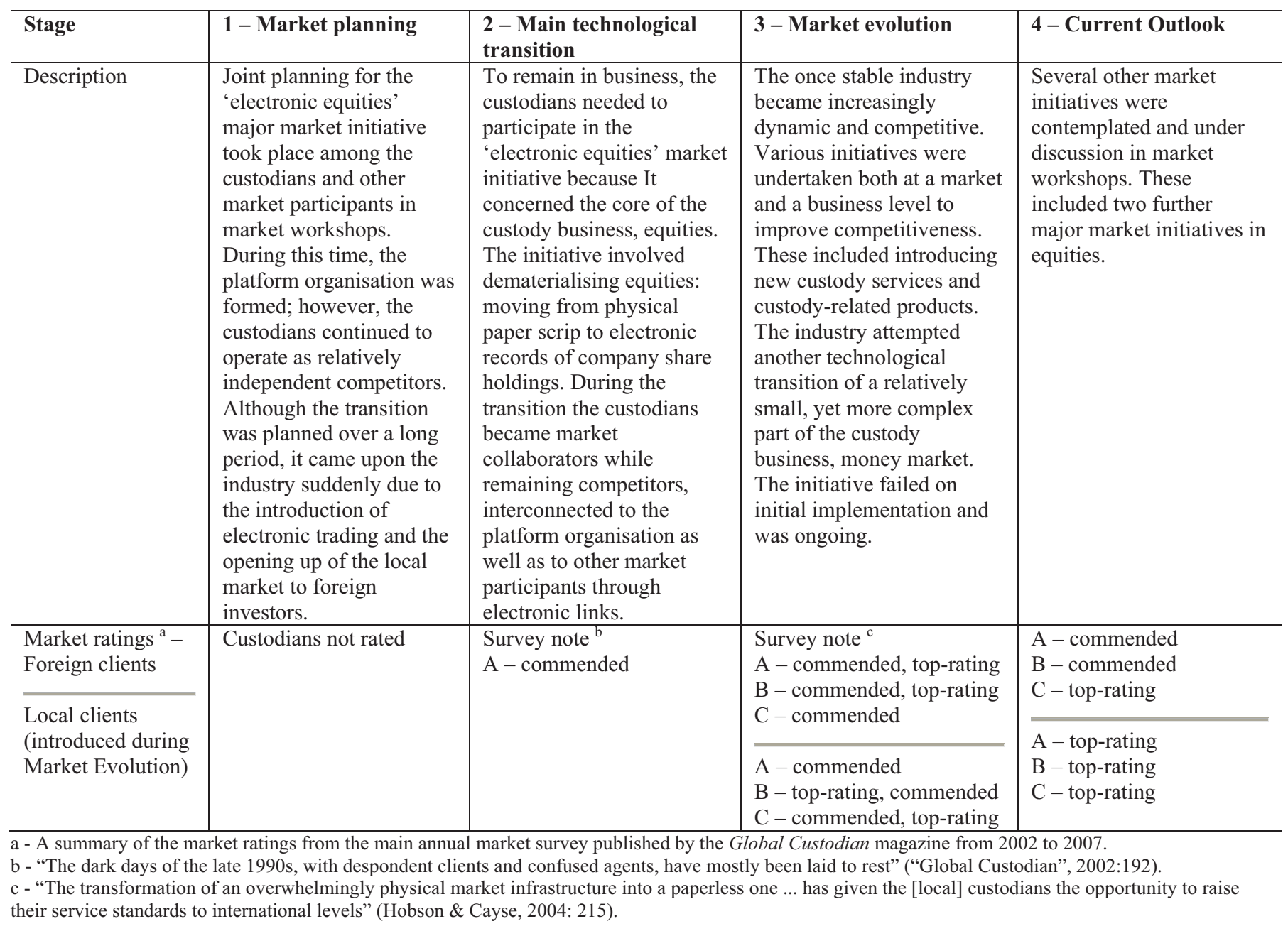

\section{Data collection}

The main data source comprised retrospective and real time accounts of managers, representing their explicit learning, gathered in semi-structured interviews. The interviews focused on the main technological transition that had taken place and the current outlook. They were conducted with about 10 informants from each organisation, selected based on their participation in, and knowledge of, the main technological transition, as well as subsequent business development. The broad scope of the study period enabled a focus on significant events, such as difficulties faced and how they were overcome. These events were likely to be best remembered in terms of their vividness at the time, due to the profound impact the technological transition had on the industry. A focus on the current outlook provided an indication of recent and cumulative learning as well as expectations and intentions going forward. Other data 
sources included archival data, such as supporting documents from the three organisations, as well as the platform organisation; basic industry compliance training material; related public documents available on the internet; and a brief job history of each informant.

Three types of interviews were conducted with each organisation. First, preliminary interviews were held with the business head and research coordinator of each organisation, mainly to arrange access and select informants. A confidentiality agreement was signed with each organisation due to the competitiveness and reputation of the industry. Notes were taken at these interviews. Second, a focus group interview of about two hours was held with most of the informants present. The workshop was loosely structured enabling one informant's recall of events to trigger another's recall. The workshop served to heighten recall of events as well as help minimise bias because events could be validated by others. It was recorded and the transcript verified by the research coordinator. Third, individual interviews of about one hour were conducted with each informant. The interviews clarified the informant's job history as previously outlined on a form, probed points made in the workshop, and focused mainly on the current situation and outlook. Each interview was recorded and the respondent asked to verify the transcript.

\section{Data analysis}

Two research strategies were used to analyse the data, namely: building theory from cases and analysing process data. Theory building from cases aims to reconcile evidence across cases and types of data, as well as between cases and literature, increasing the likelihood of creative reframing (Eisenhardt, 1989a). The emergent theory is developed by identifying patterns of relationships among constructs within and across cases as well as their underlying rationale (Eisenhardt \& Graebner, 2007). An embedded case design allowed replication logic to be applied at each unit of analysis: organisation, and innovation process. Replication of a pattern across cases helps perceive patterns and eliminate chance associations because individual cases can be used for independent corroboration of propositions (Eisenhardt, 1989a). The cross case analysis enabled comparison of three organisations and 10 innovation processes, resulting in 29 problem solving approaches. Comparison of multiple problem solving approaches contributed towards the generality of findings.

Analysing process data aims to find similarities across organisations and to develop process theory. A process theory argues for patterned sequences of events (Abbott, 1990). It explains how a change occurs over time based on a sequence of events (Van de Ven, 2007). Events in process research can be likened to constructs in variance research, and incidents, operational empirical observations, to variables (Van de Ven, 2007). Propositions help to explain patterns, sequences of events showing cause-effect relationships. The analysis traced learning events at multiple levels of analysis, ranging from descriptive events to more abstract interpretations of specific learning that took place.

Notably, a novel analytical approach combined both research strategies. Pattern templates were constructed at each level of analysis, entailing a creative contribution to observation. The templates were broadly interpretive in the sense that, in each case, there was missing and incomplete data, relevant and irrelevant data, which had to be sorted and grouped into sets of events. The analysis involved selecting which data to include and in which order, the latter not always being obvious. Not all events occurred in each case and the incidents relating to an event were idiosyncratic to each organisation. An iterative analysis was performed using the comparative method to reveal common patterns. The comparative method involves developing and juxtaposing alternative theories and then determining which theory better explains the data or how they are combined (Van de Ven, 2007). The approach involved developing a hypothesis of a pattern based on available information, in the form of a template, and then testing it across relevant problem solving approaches using replication logic. The meaning of an event, what is significant about the way it unfolds, becomes clearer when it is compared with another event (Weick, 2007). The aim was to find patterns that accounted for the range of learning incidents found and to develop plausible explanations for the patterns. The analysis involved recursive cycling among case data, emerging theory, and literature (Eisenhardt \& Graebner, 2007).

The analysis proceeded through three levels. First, a case narrative was produced for each organisation. Case narratives are a descriptive chronology (Langley, 1999) including the progression or sequence of events (Pentland, 1999). As previously mentioned, the data was grouped into four stages. The three organisations were labelled A, B, and $\mathrm{C}$, and the stage in which a learning incident occurred was maintained throughout the analysis (e.g. A1, A2, A3, A4). Examples of descriptive events included: market planning, dematerialisation development, and changes brought about. The events aimed to capture managers' learning, such as: an explanation of why an organisational department was established; and lessons learnt.

Second, a within case analysis involved constructing a narrative for each problem solving approach relating to an innovation process for each organisation. It was based on pattern templates which included the causes and consequences of the focus, or emphasis, of a problem solving approach (what) and the learning efforts employed (how). The narrative focused on managers' reasoning behind the innovation approach, what they learnt as a result, and how they reinforced or adjusted their approach. The narrative method is high on accuracy, but low on simplicity and generality, in terms of theoretical criteria (Langley, 1999).

Third, cross case analysis involved arraying each organisation's problem solving approach pertaining to a particular innovation process in a pattern template in the form of a visual map. Visual mapping is an organising 
process method enabling process information to be systematically represented in an organised form (Langley, 1999). The innovation processes were grouped into technological and organisational types of problem solving, resulting in 11 and 18 problem solving approaches respectively. The innovation process template included two broad types of learning events, identified as expert and entrepreneurial, for both the 'what' and 'how' of a problem solving strategy. Broadly, following Crossan et al. (1999), entrepreneurial learning was defined as being future possibility oriented and expert learning as being past pattern oriented. More specifically, entrepreneurial learning was indicated by a Schumpeterian aspect of introducing novelty and looking for new combinations to create value, as well as an evolutionary aspect involving promoting and shaping learning (Teece, 2009). The analysis further focused on distinguishing the two types of learning events in terms of opportunity recognition at a more detailed level.

\section{Findings: How managers recognise learning opportunities}

The analysis involved tracing critical learning events in the development process associated with an organisation's problem solving strategy; its problem solving approach for a particular innovation process. Innovation processes included identifying market direction, defining the requirements of market and business initiatives, and managing projects. These innovation processes were all part of technological innovation involving information systems development in the particular case setting.

Two types of problem solving strategies were found. Technological problem solving strategies involved interpreting the changing environment. These strategies were developed for innovation processes such as: identifying market direction, defining the requirements of market and business initiatives, and improving business processes. Learning efforts employed in the processes involved the use of analytical tools and methods, such as analysing market scenarios, critically analysing market and business practices, and benchmarking business processes. Organisational problem solving strategies involved responding to the changing environment. These strategies were developed for innovation processes such as: investing in the market and in products, structuring project teams, managing projects, collaborating in market workshops, configuring custody system technology, and gaining investment support. Learning efforts made included modelling the business, allocating resources, and coordinating processes.

In addition, two learning patterns relating to how managers recognise learning opportunities were found, as well as variants of each pattern for technological and organisational problem solving. The distinction between these two patterns, expert and entrepreneurial, is explained more fully in the discussion section. Each pattern is described in terms of its learning events for both types of problem solving and illustrated with case examples.

\section{Expert learning}

In the expert learning pattern, opportunity recognition typically occurs as a result of a series of three learning events. Their unexpected nature is often indicated by a change in thinking. An opportunity realisation event follows. The learning events are shown in Table 2.

Table 2: Expert learning pattern

\begin{tabular}{|c|c|c|}
\hline Learning event & Innovation process & Learning benefit (italics) and opportunity (underlined) \\
\hline \multicolumn{3}{|l|}{ Technological problem solving } \\
\hline \multirow{5}{*}{$\begin{array}{l}\text { An unexpected learning benefit of } \\
\text { a method or tool is recognised } \\
\text { with more adapted or prolonged } \\
\text { use }\end{array}$} & \multirow{5}{*}{$\begin{array}{l}\text { Identifying market direction } \\
\begin{array}{l}\text { Defining business } \\
\text { requirements }\end{array} \\
\begin{array}{l}\text { Improving business } \\
\text { processes }\end{array}\end{array}$} & \multirow{2}{*}{$\begin{array}{l}\text { C3 - Analysing market scenarios (to comply with bank practice of } \\
\text { business planning) forced a forward view of the business }\end{array}$} \\
\hline & & \\
\hline & & \multirow[t]{2}{*}{$\begin{array}{l}\text { B2 - More thorough analysis of business requirements to reduce } \\
\text { operational risk helped determine longer term requirements }\end{array}$} \\
\hline & & \\
\hline & & $\begin{array}{l}\text { B3 - An annual survey was a process benchmarking tool to engage clients } \\
\text { vs. a marketing tool, and it measured innovation speed vs. business } \\
\text { success } \\
\text { C3 - Foreign clients set a service level benchmark that could be passed on } \\
\text { to local clients }\end{array}$ \\
\hline $\begin{array}{l}\text { Self-reinforcing, positive effects } \\
\text { of learning efforts are slowly } \\
\text { recognised in the business }\end{array}$ & $\begin{array}{l}\text { Improving business } \\
\text { processes }\end{array}$ & $\begin{array}{l}\text { B3 - Improving operational processes made more time available for client } \\
\text { service } \\
\text { C1 - Improved operational processes were more stringent } \\
\text { C3 - Improving staff proficiency through process benchmarking was self- } \\
\text { reinforcing }\end{array}$ \\
\hline \multirow{2}{*}{$\begin{array}{l}\text { An unexpected, significant } \\
\text { business benefit is suddenly } \\
\text { recognised, after a gradual } \\
\text { learning process of related } \\
\text { recognitions. The benefit is } \\
\text { typically associated with a need }\end{array}$} & \multirow{2}{*}{$\begin{array}{l}\text { Identifying market direction } \\
\text { Improving business } \\
\text { processes }\end{array}$} & $\begin{array}{l}\text { B4 - Need to respond proactively vs. reactively to market initiatives } \\
\text { C4 - Need to prepare for a market initiative vs. wait for it }\end{array}$ \\
\hline & & $\begin{array}{l}\text { B3 - Business was about client service vs. processing } \\
\text { C3 - Foreign clients were interested in service vs. business challenges }\end{array}$ \\
\hline $\begin{array}{l}\text { Once a need is recognised the } \\
\text { respective problem solving } \\
\text { strategy is adapted to meet the } \\
\text { need }\end{array}$ & $\begin{array}{l}\text { Improving business } \\
\text { processes }\end{array}$ & $\begin{array}{l}\text { B3 - Focus on improving client service vs. achieving a top market rating } \\
\text { C3 - Focus on improving client service vs. no particular client strategy }\end{array}$ \\
\hline
\end{tabular}


Second, self-reinforcing, positive effects of learning efforts are slowly recognised in the business. Examples are: in B's learning on improving business processes, the improvement was found to make more time available for client service. A manager explained: "What we did with the technology allowed us to look [at] it more from an exception perspective, and that freed up some time to allow servicing the client"; and in B's learning about market collaboration, standardising processes was seen to help advance the market. A manager explained: "[There] also was the collaborative component in terms of what is standard practice. In the past, it was seen as a competitive advantage not to share information around the process. Post [the main technological transition] it became a necessity to standardise at least a settlement component. That required more market participation, and that kind of conversation has taken the market further".

Third, an unexpected, significant business benefit is suddenly recognised after a gradual learning process of related recognitions. The benefit is typically associated with a need and relates to a general capability required in the innovation process. Finally, once a need is recognised the respective problem solving strategy is adapted to meet the need, becoming more targeted and long term oriented. Examples are: in C's learning on identifying market direction, given that a prior initiative was found to be costly when market direction was largely unknown, a forward view of the business, gained by analysing market scenarios, was seen to enable it to prepare for a market initiative, in contrast to its earlier approach of waiting for it to happen. The manager explained: "[The question now is,] "How are we going to gear ourselves to deal with that change?" That's going to be the key thing for ourselves to determine whether the [custodians] will be something that we can still talk about in five to ten years from now.' As a result its focus on business planning was adapted to prepare for an initiative rather than to merely comply with the bank practice; in B's learning on improving business processes, managers changed their conception of the business over time, post the main technological transition. A manager observed that a "paradigm shift [took place] ... from 'processing shop' to 'client centred [service]'”. As a result its focus changed from achieving a top market rating to improving client service; and in B's learning on managing projects, a need was identified for continuous improvement rather than on a once-off basis, also post the main technological transition. A manager explained: "That mindset change [happened] when [the platform organisation] was implemented. It wasn't as if this was one big task and now we're done with it". As a result, its focus was adapted to developing business best practices.

The following proposals are made in terms of expert learning. An opportunity is a significant business benefit enabled by specific knowledge developed as a result of learning efforts employed in the innovation process. The business benefit relates to how the innovation process should be performed, such as responding proactively to market initiatives, providing superior client service, and improving continuously. Opportunity recognition occurs through learning efforts employed within the context and specific knowledge developed as a result. It takes places through a gradual learning process of related recognitions including: the value of specific knowledge developed through learning efforts to the innovation process; of small, self-reinforcing business benefits associated with the learning efforts; and then of the opportunity. The benefits are unexpected because the usefulness of the knowledge is only seen once it is developed. In particular, recognition of the opportunity represents a critical turning point in the evolution of the problem solving strategy because it results in a change in the problem solving intent. In other words, the problem solving intent becomes realising the significant business benefit., The problem solving intent becomes more abstract and general, the more targeted and longer term the nature of the business benefit is. Opportunity realisation involves adapting the problem solving strategy to focus on or emphasise obtaining the required business benefit by directing learning efforts to develop the specific knowledge.

\section{Entrepreneurial learning}

In the entrepreneurial learning pattern, opportunity recognition typically occurs as a result of two learning events. In addition, there are four variations in the opportunity recognition event. An opportunity realisation event follows. The learning events are shown in Table 3.

A need for a general learning benefit, such as a basic or fundamental understanding or competency, is recognised based on contextual constraints of the innovation process. The learning benefit relates to general knowledge required in the innovation process. Examples are: in B's learning on identifying market direction, a need for greater awareness of the interconnected global market was identified. A manager noted: "You have to be more aware of what's happening globally. You have to know what's happening with the bank globally. Your antenna has to be out there.... It's about the quality of the awareness"; and in A's learning on investing in the market and in products, a need for certainty in settling market transactions was seen prior to the main technological transition. A manager noted: "We knew that we wanted settlement certainty.... That was what we were aiming for. And we had to find a way within the confines of the [local] market ... to get there."

Particular learning efforts that help to achieve a general learning benefit required within the context can be recognised in four different ways. First, a new way of learning is observed to help achieve a general learning benefit required within the context. For example, in A's learning on defining the requirements of major market initiatives, the implementation of an end product in the 'electronic money market initiative', even though it failed, acted as a prototype solution and was seen to help participants understand basic market requirements. A manager observed, "And sometime until people see the actual finished product in front of them.... that's when you get down to the real bottom of the requirements". 
Table 3: Entrepreneurial learning pattern

\begin{tabular}{|c|c|c|}
\hline Learning event & Innovation process & Opportunity (underlined) and learning benefit (italics) \\
\hline \multicolumn{3}{|l|}{ Technological problem solving } \\
\hline \multirow[t]{3}{*}{$\begin{array}{l}\text { A need for a general } \\
\text { understanding is recognised } \\
\text { based on contextual constraints }\end{array}$} & $\begin{array}{l}\text { Identifying market } \\
\text { direction }\end{array}$ & \multirow[t]{2}{*}{$\begin{array}{l}\text { B4 - Need a better quality of market awareness } \\
\mathrm{C} 4 \text { - Need a continuous assessment of market changes to create mental } \\
\text { awareness }\end{array}$} \\
\hline & \multirow{2}{*}{$\begin{array}{l}\text { Defining market } \\
\text { requirements }\end{array}$} & \\
\hline & & $\begin{array}{l}\mathrm{C} 2 \text { - Need sustainable system development based on a better } \\
\text { understanding of market requirements }\end{array}$ \\
\hline $\begin{array}{l}\text { A new method or tool is } \\
\text { observed to help achieve a need } \\
\text { within the context }\end{array}$ & $\begin{array}{l}\text { Defining market } \\
\text { requirements }\end{array}$ & $\begin{array}{l}\text { A } 3 \text { - A product implementation (prototype solution) of a market } \\
\text { initiative, although it failed, helped participants to understand market } \\
\text { requirements in-depth }\end{array}$ \\
\hline $\begin{array}{l}\text { Once a method or tool is } \\
\text { recognised to help achieve a } \\
\text { need, it is deliberately used }\end{array}$ & $\begin{array}{l}\text { Defining market } \\
\text { requirements }\end{array}$ & $\begin{array}{l}\text { A1-3, C2 - Experienced analysts clarified and integrated market } \\
\text { requirements } \\
\text { C2 - A front-end tool (prototype solution) was used to help understand } \\
\text { how the new system (market platform) as a whole was working }\end{array}$ \\
\hline \multicolumn{3}{|l|}{ Organisational problem solving } \\
\hline \multirow{3}{*}{$\begin{array}{l}\text { A need for a general competency } \\
\text { is recognised based on contextual } \\
\text { constraints }\end{array}$} & $\begin{array}{l}\text { Investing in the market and } \\
\text { in products }\end{array}$ & $\begin{array}{l}\text { A1 - Need settlement certainty in the market ridding it of the risk of } \\
\text { paper scrip }\end{array}$ \\
\hline & $\begin{array}{l}\text { Structuring project teams } \\
\text { Collaborating in market } \\
\text { workshops }\end{array}$ & $\begin{array}{l}\text { A2 - Need a bridge between the business and the IT department } \\
\text { B4 - Need a balancing act between tracking the pace of market change } \\
\text { and continuously improving the business } \\
\text { C4 - Need to operate at a broader level }\end{array}$ \\
\hline & & $\begin{array}{l}\mathrm{C} 2-\text { Need effective interaction in market workshops to negotiate } \\
\text { requirements }\end{array}$ \\
\hline \multirow{3}{*}{$\begin{array}{l}\text { Once recognised, a known way } \\
\text { of organising is repeatedly } \\
\text { observed to help achieve a need } \\
\text { within the context. Similarly, not } \\
\text { using a known way of organising } \\
\text { is repeatedly observed to impede } \\
\text { the achievement of a need within } \\
\text { the context }\end{array}$} & $\begin{array}{l}\text { Collaborating in market } \\
\text { workshops }\end{array}$ & $\begin{array}{l}\text { A3 - A parallel was drawn between two major market initiatives where } \\
\text { some market participants had not had appropriately competent people }\end{array}$ \\
\hline & Gaining investment support & $\begin{array}{l}\text { requirements } \\
\mathrm{C} 4 \text { - Staff involvement in market workshops enabled them to focus } \\
\text { more broadly }\end{array}$ \\
\hline & & $\begin{array}{l}\mathrm{C} 4-\text { Regular business reporting to the bank enabled greater visibility } \\
\text { within the bank }\end{array}$ \\
\hline \multirow{3}{*}{$\begin{array}{l}\text { A known way of organising } \\
\text { which can be applied to help } \\
\text { achieve a need within the context } \\
\text { is recognised }\end{array}$} & Structuring project teams & \multirow{3}{*}{$\begin{array}{l}\text { A2 - Separating product development from operations (previously } \\
\text { known) to prevent operations from being distracted by ongoing market } \\
\text { changes } \\
\text { B4 - Separating teams by project time horizon (seen in another } \\
\text { department) to enable simultaneous focus on current and future } \\
\text { initiatives }\end{array}$} \\
\hline & & \\
\hline & & \\
\hline \multirow{4}{*}{$\begin{array}{l}\text { A new way of organising which } \\
\text { can be applied to help achieve a } \\
\text { need within the context is } \\
\text { recognised }\end{array}$} & $\begin{array}{l}\text { Investing in the market and } \\
\text { in products }\end{array}$ & $\begin{array}{l}\text { C3 - Separating commodity and competitive advantage in the market } \\
\text { model to prevent infrastructure duplication (implied to enable focus) }\end{array}$ \\
\hline & Managing projects & \multirow{2}{*}{$\begin{array}{l}\text { A } 2 \text { - Planned a fast equities dematerialisation process to minimise the } \\
\text { risk of possible tainted scrip in the business (implied to be done } \\
\text { competently) }\end{array}$} \\
\hline & Configuring custody & \\
\hline & & $\begin{array}{l}\text { B1 - A novel system configuration of separating custody technologies } \\
\text { to facilitate a technological transition (implied to enable focus) }\end{array}$ \\
\hline \multirow{6}{*}{$\begin{array}{l}\text { Once a way of organising is } \\
\text { recognised to help achieve a } \\
\text { need, it is deliberately used, } \\
\text { failing which it is promoted }\end{array}$} & $\begin{array}{l}\text { Investing in the market and } \\
\text { in products }\end{array}$ & $\begin{array}{l}\text { C3 - A more centralised market model separating commodity and } \\
\text { competitive advantage was promoted }\end{array}$ \\
\hline & Structuring project teams & \multirow{2}{*}{$\begin{array}{l}\text { A2 - A product development team was established well ahead of } \\
\text { competitors }\end{array}$} \\
\hline & Managing projects & \\
\hline & & \multirow{2}{*}{$\begin{array}{l}\text { A2 - A fast dematerialisation process was implemented ahead of } \\
\text { competitors }\end{array}$} \\
\hline & \multirow{2}{*}{$\begin{array}{l}\text { Configuring custody } \\
\text { system technology }\end{array}$} & \\
\hline & & lated risk was taken in implementing dual custody systems \\
\hline
\end{tabular}

Second, once recognised, a known way of learning is repeatedly observed to help achieve a general learning benefit required within the context. Similarly, not using a known way of learning is repeatedly observed to impede the achievement of a general learning benefit required within the context. Examples are: in C's learning on gaining 
investment support, a marked change in the visibility of the business in the bank was attributed in part, to regular risk reporting reflecting an increasingly critical effect of the business on the bank risk profile. A manager noted: "There's a lot of visibility and transparency that wasn't there before"; and in A's learning on collaborating in market workshops, a manager drew a parallel between two major market initiatives to explain why broker trading practice requirements had not initially been addressed in the former initiative, given that a similar situation occurred with issuer requirements in the latter initiative: "because [members of] the broking community themselves ... had not being closely involved in the working sessions".

Third, a known way of learning which can be applied to help achieve a general learning benefit required within the context is recognised. For example, in B's learning on structuring project teams, managers recognised a principle of separating the teams based on type of initiatives undertaken to prevent role conflict problems in another department and subsequently applied it to their own teams. A manager explained: "They went through all the problems and the troubles. We saw of all this. And they separated their teams and called them a [support] team and a [development] team".

Fourth, a new way of learning which can be applied to help achieve a general learning benefit required within the context is recognised. For example, in B's learning on configuring custody system technology, a dual system implementation was designed in the first stage to facilitate stock reconciliation during a technology transition in the second stage. The design was later found to facilitate the transition in other ways because it enabled focus. A manager explained: "We kept the two [systems] together, but separate.... And [it] allowed us the ability to communicate with [the platform organisation] a lot quicker, and [to] get that whole project moving in a quicker manner because now we were focused on one thing."

Finally, once a way of learning is recognised to help achieve a general learning benefit required within the context it is deliberately used, failing which it is promoted. Examples are: in C's learning on defining the requirements of major market initiatives, a front-end tool was deliberately used as a prototype solution in the electronic equities initiative to help understand market requirements. A manager explained: "we could figure out from the daily transactions which were coming through, how this thing was really working.... There was a strategy behind it"; and in B's learning on configuring custody system technology, a calculated risk was taken in implementing dual custody systems. A manager explained: "We did the separate implementation ... because we went [with] the electronic [system] as much as to say, "[the platform organisation] is going there", when we didn't know [the operating model]. So we took a calculated risk because we knew we could operate the business like that".

The following proposals are made in terms of entrepreneurial learning. The problem solving intent is an abstract and general learning benefit or knowledge required in the context of the innovation process, such as a basic or fundamental understanding or competency. The learning benefit relates to the type of knowledge that should be developed as a result of learning efforts in the innovation process, such as a better quality of market awareness, an indepth understanding of market requirements, settlement certainty, a bridge between two project teams, and operational focus without distraction. An opportunity is a way of learning which can help achieve the problem solving intent. Given that the problem solving intent is known, four types of opportunity recognition can occur involving either a new or known way of learning, observed within or applied to the context, to help achieve the problem solving intent. In other words, the way of learning is recognised to help develop the required knowledge. Opportunity realisation involves employing or promoting the way of learning within the context to develop the required knowledge.

\section{Discussion}

This article investigates how managers recognise learning opportunities. Recognition of these opportunities can lead to the development of dynamic capabilities. Technological innovation involving information systems development is examined in three securities custodians operating in a market that changed from relatively static to highly dynamic, making it suitable for the development of dynamic capabilities. Process analysis of the data revealed common learning patterns relating to two types of learning, expert and entrepreneurial, and recognition of both technological and organisational innovation opportunities.

The dynamic capability learning framework (Lecler, 2013) shown in Figure 1 is elaborated and extended. The framework shows the four distinct learning patterns that were found. It enables learning experiences relating to opportunity recognition and dynamic capability development to be captured by using it as a tool to analyse data. Thus, it helps to operationalise the complex concepts of dynamic capabilities, organisational learning, and entrepreneurship.

The first dimension of the framework distinguishes between expert and entrepreneurial learning. The terminology derives from a distinction between these types of individual intuition in Crossan et al.'s (1999) organisational learning framework, as well as a learning perspective of entrepreneurial opportunities (Dutta \& Crossan, 2005). The concept of entrepreneurial learning is elaborated to help explain how managers recognise learning opportunities. Notably, the term is used in a qualitative sense to refer to a type of learning process, as opposed to a descriptive sense to refer to learning by people known as entrepreneurs (e.g. Holcomb, Ireland, Holmes \& Hitt, 2009). The second dimension of the framework distinguishes between technological and organisational opportunities in terms of interpreting and responding to a changing environment respectively. To achieve a high level of performance an 
organisation needs to respond fast as well as appropriately (Prahalad \& Bettis, 1986).

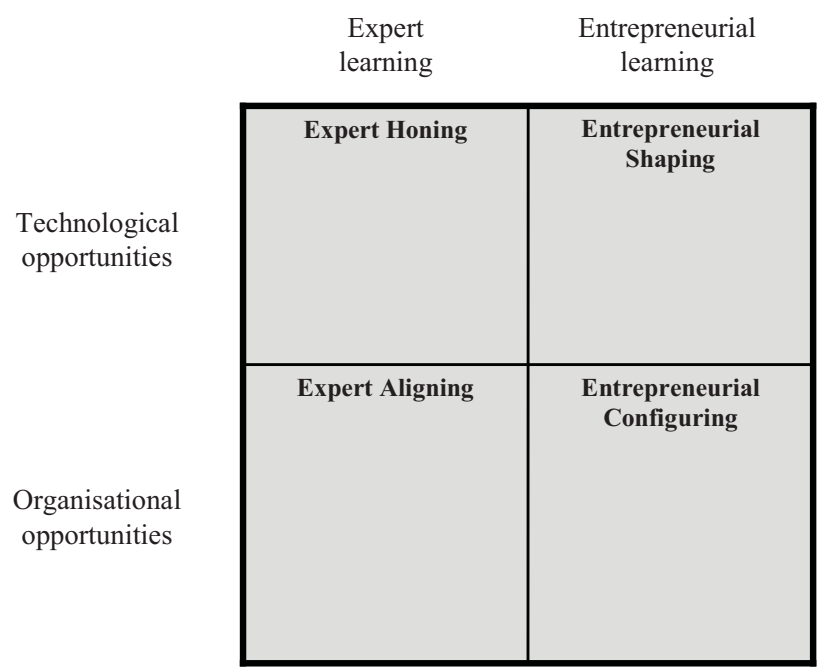

Figure 1: Dynamic capability learning framework

Further, more detailed characteristics distinguishing the two types of learning are proposed in terms of opportunity recognition and realisation and new characteristics are proposed in terms of the nature of the problem solving strategy, summarised in Table 4. Although the two types of learning can be complementary their characteristics are deliberately juxtaposed to highlight the differences. In addition, implications of entrepreneurial learning in terms of developing dynamic capabilities are highlighted.

Table 4: Characteristics of expert learning and entrepreneurial learning

\begin{tabular}{l|l|l}
\hline & Expert learning & $\begin{array}{l}\text { Entrepreneurial } \\
\text { learning }\end{array}$ \\
\hline $\begin{array}{l}\text { Opportunity } \\
\text { recognition }\end{array}$ & $\begin{array}{l}\text { Serendipitous } \\
\text { Opportunity } \\
\text { discovery }\end{array}$ & $\begin{array}{l}\text { Intentional search } \\
\text { Opportunity design }\end{array}$ \\
\hline $\begin{array}{l}\text { Opportunity } \\
\text { realisation }\end{array}$ & $\begin{array}{l}\text { Strategy adapted } \\
\text { Path dependent - } \\
\text { honing and aligning } \\
\text { Kirznerian view of } \\
\text { entrepreneurship }\end{array}$ & $\begin{array}{l}\text { Opportunity enacted } \\
\text { Path breaking - } \\
\text { shaping and } \\
\text { configuring } \\
\text { Schumpeterian view } \\
\text { of entrepreneurship }\end{array}$ \\
\hline $\begin{array}{l}\text { Problem } \\
\text { solving } \\
\text { strategy }\end{array}$ & $\begin{array}{l}\text { Selection } \\
\text { Intent - significant } \\
\text { business benefit }\end{array}$ & $\begin{array}{l}\text { Procedural } \\
\text { Intent - general } \\
\text { learning benefit }\end{array}$ \\
\hline
\end{tabular}

\section{Opportunity recognition}

In expert learning, opportunity recognition occurs through a gradual learning process where knowledge developed is recognised to have unexpected benefits, including: a learning benefit; then small, self-reinforcing business benefits; and then to enable a strategic business benefit. It results in a change in strategic intentions that can be described as a mindset change or a paradigm shift, comparable to changing a dominant logic (Bettis \& Prahalad, 1995). Consistent with empirical research, it involves a lengthy unlearning process and an ongoing learning process (Barr et al., 1992) as well as the development of prior related knowledge (Baron \& Ensley, 2006; Shane, 2000).

Thus, opportunity recognition is not part of an intentional search. Rather, it is the result of learning efforts with a different intent, directed at solving a different problem. In this sense, the process is serendipitous with the opportunity only discovered after some time and requiring alertness to recognise the appearance of a new possibility (Denrell et al., 2003).

An opportunity is a significant business benefit enabled by specific knowledge developed as a result of learning efforts employed in the innovation process. The knowledge is recognised to have proven value within the context in which it is developed. Thus, the opportunity exists and is discovered, and is likely to be part of a complex combination of resources used in a different way (Denrell et al., 2003). Discovery requires the identification of new means-ends relationships generated by a particular change (Shane \& Venkataraman, 2000). In particular, a new end is identified for a particular means. It is suggested to be based on prior knowledge required to recognise it and the development of cognitive schema required to evaluate it (Shane \& Venkataraman, 2000). Recognition may involve an evaluation process (Grégoire et al., 2010) where experience is used to 'connect the dots' due to welldeveloped prototypes or templates of 'ideal' opportunities (Baron \& Ensley, 2006). Consistent with the Kirznerian view of entrepreneurship, the value of new information is discovered based on prior related knowledge rather than searching for required knowledge (Shane, 2000). Opportunity discovery could involve analogical reasoning based on more specific analogies because specific knowledge developed is matched to a significant business benefit.

In contrast, in entrepreneurial learning, opportunities are recognised in line with strategic intentions. The usefulness of the type of knowledge required within the context is recognised before it is developed. Thus, opportunities are recognised as part of an intentional search. Consistent with empirical research, prior knowledge of markets is used to search for opportunities of new technologies (Grégoire et al., 2010).

An opportunity is a way of learning which can help achieve the problem solving intent. It is a means, such as a method, tool, or way of organising, to develop the type of required knowledge. Given that the problem solving intent or generally required knowledge is known, there can be four types of opportunity recognition. First, a new means is recognised operating within the context to help develop the generally required knowledge. For example, the usefulness of a particular technology is matched to a market situation. Second, once it is identified, it becomes a known means to continually help develop the generally required knowledge. Third, recognition occurs of a known means which can be applied within the context to develop the generally required knowledge, such as technology transfer across domains. 
Finally, recognition occurs of a new means which can be applied within the context to develop the generally required knowledge.

Opportunity recognition involves identifying a new meansends relationship, where the means is identified to achieve more general ends. Because of their contingent nature, based on available resources found, opportunities embody a teleological process and can be designed (Venkataraman et al., 2010). Design of an opportunity involves a purposeful application of resources to address a particular contextual requirement. It relates to the choice of boundary values for variables, and control of the design relates to the means to change the boundary values (Venkataraman et al., 2010). In this respect, the effect created, or the degree to which the problem solving intent is achieved, depends on setting the boundary values. Opportunity design could involve analogical reasoning based on more abstract analogies, because the type of knowledge required is matched to a means of developing it. Such reasoning can generate unique and novel solutions which can partially construct the environment (Farjoun, 2008). It is also consistent with prior research findings which show a technology-market match involves aligning structural relationships, such as technology capabilities, rather than superficial similarities, to market needs (Grégoire et al., 2010).

\section{Opportunity realisation}

In expert learning, an opportunity is realised by adapting the problem solving strategy to further develop the required knowledge and obtain the strategic business benefit. Adapting the strategy requires flexibility in redirecting efforts (Denrell et al., 2003). The strategy is 'honed' to focus on developing the required knowledge, and 'aligned' with the environment to emphasise the required knowledge development in terms of technological and organisational opportunities respectively. Thus, opportunities discovered are path dependent and can lead to self-reinforcing effects with increasing returns to adoption. Consistent with the Kirznerian view of entrepreneurship, adapting a problem solving strategy closes gaps in problem solving.

In entrepreneurial learning, opportunity realisation involves deliberately enacting or promoting the means. Because the means is a way of learning, enacting it helps to develop the generally required knowledge. Enacting an opportunity involves a level of calculated risk because the means is not already employed within the situation for the particular purpose. It is path breaking because it involves a change in contextual relationships, although the degree of path breaking change may vary. Thus, it has a modifying effect on the context, shaping and configuring it in terms of technological and organisational opportunities respectively. The terms 'shaping' and 'configuring' are derived from an 'evolutionary with design' perspective of dynamic capabilities, where they are referred to as the "capacity to shape, reshape, configure, and reconfigure assets so as to respond to changing technologies and markets" (Teece, 2009: 87). Consistent with the Schumpeterian view of entrepreneurship, enacting an opportunity involves a novel design and results in disruptive change. Thus, the framework proposed, based on the findings, contrasts with arguments that suggest the Kirznerian view of entrepreneurship may include enactment as well as discovery of opportunities (Dutta \& Crossan, 2005).

\section{Problem solving strategy}

In expert learning, the problem solving intent changes to the significant business benefit; for example, responding proactively to market initiatives, providing superior client service, and improving continuously. It becomes more abstract and general, consistent with empirical research (e.g. Barr et al., 1992; Bingham \& Eisenhardt, 2011). Following Bingham and Eisenhardt's (2011) types of managerial heuristics learnt in capability development, the type of strategy is 'selection', guiding particular knowledge to develop to obtain a business benefit. A selection strategy is the 'what' of strategy. It is content oriented and helps to constrain the range of opportunities an organisation may pursue.

In entrepreneurial learning, the problem solving intent is a more general and abstract learning benefit, such as a better quality of market awareness, more sustainable system development, a bridging function, and a broader level of operating. It relates to development of the type of knowledge required. Again, following Bingham and Eisenhardt's (2011), the type of strategy is procedural. A procedural strategy is the 'how' of strategy. It is process oriented, guiding the learning approach taken and how knowledge is developed. It helps to open up the range of opportunities an organisation may pursue.

In summary, the dynamic capability learning framework identifies distinctive characteristics of expert and entrepreneurial learning. The essential differences in opportunity recognition between the two types of learning respectively are whether: the opportunity is recognised serendipitously and discovered, or is recognised as part of an intentional search and designed; the effect of the realised opportunity on the context is adaptive or modifying; and the type of problem solving strategy is selection, focusing on a business capability, or procedural, focusing on a technological capability.

\section{Implications of entrepreneurial learning: Development of dynamic capabilities}

Entrepreneurial learning is suggested to be especially suited to recognising learning opportunities in fast changing environments, compared with expert learning. It can facilitate the development of dynamic capabilities in at least three ways. First, problem solving strategies are procedural, focusing on how to develop knowledge or 'know-how', rather than on what knowledge to develop. As a result, more general, yet flexible knowledge is likely to be developed more quickly and have to wider application enabling it to be leveraged in multiple situations. In hypercompetitive 
environments, procedural strategies are likely to be more relevant, because selection strategies based on stable patterns of competitive content can become rapidly outdated (Bogner \& Barr, 2000).

Second, because the problem strategy is procedural, the problem solving intent can be realised to varying degrees and achieved in multiple ways. It involves constantly searching for new and better ways. Entrepreneurial management is not about analysing and optimising, but more about sensing and understanding opportunities, getting things started, and finding new and better ways to assemble things (Teece, 2007). An enacting mode of interpretation rather than a discovery mode indicates that managers believe the environment is less analysable (Daft \& Weick, 1984). In such fast moving environments, experiential strategies have been found to be more effective than a more planned approach (e.g. Eisenhardt, 1989b; Eisenhardt \& Tabrizi, 1995).

Third, opportunities enacted are path breaking and have a modifying effect on the context. They are designed to address a particular contextual requirement. Realising learning opportunities helps to shape learning processes and configure learning resources and assets, resulting new and better ways to develop knowledge. Higher order capabilities, of the 'learning to learn' variety, can help overcome the path dependence associated with the development of the original, lower order capabilities (Collis, 1994). In a highly dynamic environment, a path breaking logic of strategic opportunity (Eisenhardt \& Martin, 2000) may be required to develop new knowledge and spur growth.

In summary, given a rapidly changing and competitive environment, entrepreneurial learning can facilitate dynamic capability learning. Procedural problem solving strategies are less likely than selection strategies to become outdated in a rapidly changing environment, experiential strategies involving a continuous search for new and better ways to develop knowledge are likely to be more effective than a more planned approach, and enacting path breaking learning opportunities can open up new possibilities for knowledge development.

\section{Conclusion}

This article aims to develop process theory on how managers recognise learning opportunities. These opportunities can lead to the development of dynamic capabilities. It reports on part of a broader study that examined how dynamic capabilities develop through learning. The process analysis aims to find similar learning patterns across organisations by tracing learning events related to technological innovation. The novel analytical approach helps to refine and validate the learning patterns found by interpreting their characteristics.

The main claim is that managers recognise learning opportunities through two types of learning, expert and entrepreneurial, with variants for both technological and organisational problem solving. Based on the dynamic capability learning framework (Lecler, 2013), this article develops a more detailed characterisation of the two types of learning in terms of opportunity recognition and realisation, and further proposes characteristics pertaining to the nature of the problem solving strategy. The concept of entrepreneurial learning is elaborated to help explain differences in the learning patterns found. Broadly, expert learning focuses on the 'what' of strategy and entrepreneurial learning focuses on the 'how' of strategy (Lecler, 2013).

Given that entrepreneurial learning is likely to be well suited to opportunity recognition in a highly dynamic environment, its implications in terms of the broader question of dynamic capability development are highlighted. A related implication for management practice is that problem solving focusing on the 'how' of strategy and on developing 'know how' is likely to facilitate innovation in fast changing environments. Avenues for future research include a more detailed and extended characterisation of the two types of learning in the dynamic capability learning framework, including problem framing and search processes. For instance, research on causal and effectual reasoning approaches suggests that they are based on distinctly different ways of representing problems (Sarasvathy, 2001; Sarasvathy, Simon \& Lave, 1998). In addition, the framework can be used to investigate dynamic capability learning under different environmental conditions and to better understand the nature and consequences of dynamic capabilities.

\section{References}

Abbott, A. 1990. 'A primer on sequence methods', Organization Science, 1(4): 375-392.

Adner, R. \& Helfat, C. E. 2003. 'Corporate effects and dynamic managerial capabilities', Strategic Management Journal, 24(10): 1011-1025.

Argote, L. 2011. 'Organizational learning research: Past, present and future', Management Learning, 42(4): 439-446.

Baron, R. A. \& Ensley, M. D. 2006. 'Opportunity recognition as the detection of meaningful patterns: Evidence from comparison of novice and experienced entrepreneurs', Management Science, 52(9): 1331-1344.

Barr, P.S., Stimpert, J. L. \& Huff, A. S. 1992. 'Cognitive change, strategic action, and organizational renewal', Strategic Management Journal, 13: 15-36. [online] URL:http://www.jstor.org/stable/2486350.

Bettis, R.A. \& Prahalad, C.K. 1995. 'The dominant logic: Retrospective and extension', Strategic Management Journal, 16(1): 5-14. [online] URL:http://www.jstor.org/stable/2486943. 
Bingham, C.B. \& Eisenhardt, K.M. 2011. 'Rational heuristics: The 'simple rules' that strategists learn from process experience', Strategic Management Journal, 32: 1437-1464.

Bogner, W.C. \& Barr, P.S. 2000. 'Making sense in hypercompetitive environments: A cognitive explanation for the persistence of high velocity competition', Organization Science, 11(2): 212-226. [online] URL:http://www.jstor.org/stable/2640285.

Cohen, M.D. \& Bacdayan, P. 1994. 'Organizational routines are stored as procedural memory: Evidence from a laboratory study', Organization Science, 5(4): 554-568. [online] URL:http://www.jstor.org/stable/2635182.

Collis, D.J. 1994. 'Research note: How valuable are organizational capabilities?' Strategic Management Journal, 15: 143-152. [online] URL:http://www.jstor.org/stable/2486815.

Crossan, M.M., Lane, H.W. \& White, R.E. 1999. 'An organizational learning framework: From intuition to institution', Academy of Management Review, 24(3): 522537. [online] URL:http://www.jstor.org/stable/259140.

Daft, R.L. \& Weick, K.E. 1984. 'Towards a model of organizations as interpretation systems,' Academy of Management Review, 9(2): 284-295. [online] URL:http://www.jstor.org/stable/258441.

Denrell, J., Fang, C. \& Winter, S.G. 2003. 'The economics of strategic opportunity', Strategic Management Journal, 24: 977-990.

Di Stefano, G., Peteraf, M. \& Verona, G. 2010. 'Dynamic capabilities deconstructed: A bibliographic investigation into the origins, development, and future directions of the research domain', Industrial and Corporate Change, 19(4): 1187-1204.

Dutta, D.K. \& Crossan, M.M. 2005. 'The nature of entrepreneurial opportunities: Understanding the process using the 4I organizational learning framework', Entrepreneurship Theory and Practice, July: 425-449.

Easterby-Smith, M., Crossan, M.M. \& Nicolini, D. 2000. 'Organizational learning: Debates past, present and future', Journal of Management Science, 37(6): 783-796.

Easterby-Smith, M., Lyles, M.A. \& Peteraf, M.A. 2009. 'Dynamic capabilities: Current debates and future directions', British Journal of Management, 20: S1-S8.

Eisenhardt, K.M. 1989. 'Building theories from case study research', Academy of Management Review, 14(4): 532-550.

Eisenhardt, K.M. 1989. 'Making fast strategic decisions in high-velocity environments,' Academy of Management Review, 32(3): 543-536. [online] URL:http://www.jstor.org/stable/256434.
Eisenhardt, K.M. \& Graebner, M.E. 2007. 'Theory building from cases: Opportunities and challenges', Academy of Management Journal, 50(1): 25-32.

Eisenhardt, K.M. \& Martin, J.A. 2000. 'Dynamic capabilities: What are they?' Strategic Management Journal, 21(10/11): 1105-1121. [online] URL:http://www.jstor.org/stable/3094429.

Eisenhardt, K.M. \& Tabrizi, B.N. 1995. 'Accelerating adaptive processes: Product innovation in the global computer industry', Administrative Science Quarterly, 40: 84-110.

Farjoun, M. 2008. 'Strategy making, novelty and analogical reasoning - commentary on Gavetti, Levinthal and Rivkin (2005)', Strategic Management Journal, 29: 1001-1016.

Feldman, M.S. \& Pentland, B.T. 2003. 'Reconceptualizing organizational routines as a source of flexibility and change', Administrative Science Quarterly, 48: 94-118.

Fiol, C.M. \& Lyles, M.A. 1985. 'Organizational learning', Academy of Management Review, 10(4): 803-813.

Gavetti, G. 2005. 'Cognition and hierarchy: rethinking the microfoundations of capabilities' development', Organization Science, 16(6): 599-617.

Gavetti, G. \& Levinthal, D.A. 2000. 'Looking forward and looking backward: Cognitive experiential search, Administrative Science Quarterly, 45(1): 113-137. [online] URL:http://www.jstor.org/stable/2666981.

Gavetti, G., Levinthal, D.A. \& Rivkin, J.W. 2005. 'Strategy making in novel and complex worlds: The power of analogy', Strategic Management Journal, 26: 691-712.

Global Custodian 2002 review of agent banks in major markets, South Africa. 2002. Global Custodian, Fall: 192.

Grégoire, D.A., Barr, P.S. \& Shepherd, P.A. 2010. 'Cognitive processes of opportunity recognition: The role of structural alignment', Organization Science, 21(2): 413431.

Helfat, C.E., Finkelstein, S., Mitchell, W., Peteraf, M.A. (with Maritan., C.A.), Singh, H., Teece, D.J. \& Winter, S.G. 2007. Dynamic capabilities: Understanding strategic change in organizations. Malden, MA: Blackwell Publishing.

Helfat, C.E. \& Peteraf, M.A. 2009. 'Understanding dynamic capabilities: Progress along a developmental path', Strategic Organization, 7(1): 91-102.

Hobson, D. \& Cayse, A. 2004. 'Global Custodian 2004 review of agent banks in major markets, South Africa', Global Custodian, Fall: 214-215. 
Holcomb, T.R., Ireland, R.D, Holmes, R.M., Jr. \& Hitt, M.A. 2009. 'Architecture of entrepreneurial learning: Exploring the link among heuristics, knowledge, and action', Entrepreneurship Theory and Practice, January: 167-192.

Kale, P. \& Singh, H. 2007. 'Building firm capabilities through learning: The role of the alliance learning process in alliance capability and firm-level alliance success', Strategic Management Journal, 28(10): 981-1000.

Kaplan, S. 2008. 'Cognition, capabilities, and incentives: Assessing firm response to the fiber-optic revolution', Academy of Management Journal, 51(4): 672-695.

Kirzner, I. 1973. Competition and entrepreneurship. Chicago, IL: University of Chicago Press.

Kirzner, I. 1997. 'Entrepreneurial discovery and the competitive market process: An Austrian approach', Journal of Economic Literature, 35: 60-85.

Lin, A.C. 1998. 'Bridging positivist and interpretivist approaches to qualitative methods', Policy Studies Journal, 26(1): 162-180.

Langley, A. 1999. 'Strategies for theorizing from process data', Academy of Management Review, 24(4): 691-710.

Lecler, C.J. 2013. 'Organisational learning and dynamic capabilities: A case study'. Doctoral thesis, University of Pretoria, Gordon Institute of Business Science, Johannesburg.

Levitt, B. \& March, J.G. 1988. 'Organizational learning', Annual Review of Sociology, 14: 319-340. [online] URL:http://www.jstor.org/stable/2083321.

Nelson, R.R. \& Winter, S.G. 1982. An evolutionary theory of economic change. Cambridge, MA: Belknap Harvard University Press.

O'Reilly, C.A., III, Harreld, J.B. \& Tushman, M.L. 2009. 'Organizational ambidexterity: IBM and emerging business opportunities', California Management Review, 51(4): 7599.

Pentland, B.T. 1999. 'Building process theory with narrative: From description to explanation', Academy of Management Review, 24(4): 711-724.

Prahalad. C.K. \& Bettis, R.A. 1986. 'The dominant logic: A new linkage between diversity and performance', Strategic Management Journal, 7(6): 485-501. [online] URL:http://www.jstor.org/stable/2486135.

Romme, A.G.L., Zollo, M. \& Berends, P. 2010. 'Dynamic capabilities, deliberate learning and environmental dynamism: A simulation model', Industrial and Corporate Change, 19(4): 1271-1299.
Sarasvathy, D.K., Simon, H.A. \& Lave, L. 1998. 'Perceiving and managing risks: Differences between entrepreneurs and bankers', Journal of Economic Behavior \& Organization, 33: 207-225.

Sarasvathy, S.D. 2001. 'Causation and effectuation: Toward a theoretical shift economic inevitability to entrepreneurial contingency', Academy of Management Review, 26(2): 243263. [online] URL:http://www.jstor.org/stable/259121.

Schumpeter, J. 1934. The theory of economic development. Cambridge, MA: Harvard University Press.

Shane, S. 2000. 'Prior knowledge and the discovery of entrepreneurial opportunities', Organization Science, 11(4): 448-469. [online] URL:http://www.jstor.org/stable/2640414.

Shane, S. 2012. 'Reflections on the 2010 AMR decade award: Delivering on the promise of entrepreneurship as a field of research', Academy of Management Review, 37(1): 10-20.

URL:http://dx.doi.org/10.5465/amr.2011.0078. [online]

Shane, S. \& Venkataraman, S. 2000. The promise of entrepreneurship as a field of research', Academy of Management Review, 25(1): 217-226. [online] URL:http://www.jstor.org/stable/259271.

Teece, D.J. 2007. 'Explicating dynamic capabilities: The nature and microfoundations of (sustainable) enterprise performance', Strategic Management Journal, 28: 13191350 .

Teece, D.J. (with Augier, M). 2009. Dynamic capabilities \& strategic management: Organizing for innovation and growth. New York: Oxford University Press.

Teece, D.J., Pisano, G.P. \& Shuen, A. 1997. 'Dynamic capabilities and strategic management', Strategic Management Journal, 18(7): 509-533. [online] URL:http://www.jstor.org/stable/3088148.

Van de Ven, A.H. 2007. Engaged scholarship: A guide for organizational and social research. New York: Oxford University Press.

Van de Ven, A.H. \& Poole, M.S. 1995. 'Explaining development and change in organizations', Academy of Management Review, 20(3): 510-540.

Venkataraman, S., Sarasvathy, S.D., Dew, N. \& Forster, W.R. 2010. 'Reflections on the 2010 AMR decade award: Whither the promise? Moving forward with entrepreneurship as a science of the artificial', Academy of Management Review, 37(1): 21-33. [online] URL:http://dx.doi.org/10.5465/amr.2011.0079.

Walsh, J.P. \& Ungson, G.R. 1991. 'Organizational memory', Academy of Management Review, 16(1): 57-91. [online] URL:http://www.jstor.org/stable/258607. 
Weick, K.E. 2007. 'The generative properties of richness', Academy of Management Journal, 50(1): 14-19.

Weick, K.E. \& Roberts, K.H. 1993. 'Collective mind in organisations: Heedful interrelating on flight decks', Administrative Science Quarterly, 38(3): 357-381. [online] URL:http://www.jstor.org/stable/2393372.

Winter, S.G. 2000. 'The satisficing principle in capability learning', Strategic Management Journal, 21(10/11): 981996.

Winter, S.G. 2003. 'Understanding dynamic capabilities', Strategic Management Journal, 24: 991-995.

Yin, R.K. 2003. Case study research: design and methods. Thousand Oaks, CA: Sage.

Zollo, M. \& Singh, H. 2004. 'Deliberate learning in corporate acquisitions: Post-acquisition strategies and integration capability in U.S. bank mergers', Strategic Management Journal, 25: 1233-1256.

Zollo, M. \& Winter, S.G. 2002. 'Deliberate learning and the evolution of dynamic capabilities', Organization Science, 13(3): 339-351. 